\title{
Archaeological Testing of Site 41HR564 Harris County, Texas
}

Joe T. Denton

Follow this and additional works at: https://scholarworks.sfasu.edu/ita

Part of the American Material Culture Commons, Archaeological Anthropology Commons, Environmental Studies Commons, Other American Studies Commons, Other Arts and Humanities Commons, Other History of Art, Architecture, and Archaeology Commons, and the United States History Commons

Tell us how this article helped you.

This Article is brought to you for free and open access by the Center for Regional Heritage Research at SFA ScholarWorks. It has been accepted for inclusion in Index of Texas Archaeology: Open Access Gray Literature from the Lone Star State by an authorized editor of SFA ScholarWorks. For more information, please contact cdsscholarworks@sfasu.edu. 


\section{Archaeological Testing of Site 41HR564 Harris County, Texas}

\section{Licensing Statement}

This is a work produced for the Texas Department of Transportation (TxDOT) by the report producer. TxDOT and the report producer jointly own all rights, title, and interest in and to all intellectual property developed under TXDOT's contract with the report producer. The report may be cited and brief passages from this publication may be reproduced without permission provided that credit is given to both TxDOT and the report producer. Permission to reprint an entire chapter, section, figures or tables must be obtained in advance from either the Supervisor of the Archeological Studies Branch, Environmental Affairs Division, Texas Department of Transportation, 125 East 11th Street, Austin, Texas, 78701 or from the report producer. 
ARCHAEOLOGICAL TESTING OF SITE 41HR564

HARRIS COUNTY, TEXAS

\author{
By \\ Joe T. Denton
}

Texas

State Department of Highways and Public Transportation Highway Design Division

September 1985 


\begin{abstract}
Prehistoric Site 41HR564, located in Harris County, Texas, near Keegans Bayou and US Highway 59, was tested in August 1985 to determine eligibility for inclusion within the National Register of Historic Places and State Archaeological Landmark status. Testing also was conducted to ascertain site depth and archaeological significance. No cultural materials were recovered as a result of the test and no further investigations are recommended.
\end{abstract}




\section{INTRODUCTION}

Archaeological Site $41 \mathrm{HR} 564$ was recorded at the Texas Archeological Research Laboratory of the Balcones Research Center, The University of Texas at Austin, in March 1985 by a member of the State Department of Highways and Public Transportation (SDHPT) professional cultural resources staff.

Testing of the site was conducted on August 13 and 14, 1985, by Joe T. Denton of the SDHPT professional cultural resources staff, with field support personnel provided by the SDHPT District 12 Harris Northwest Residency Office. Testing was performed under the auspices of Procedures for the Protection of Historic and Cultural Properties (36 CFR, Part 800), procedures prescribed and endorsed by the Federal Highway Administration, and a Memorandum of Agreement between the SDHPT and the Texas Antiquities Committee. The object of the testing was to determine eligibility for inclusion of the site within the National Register of Historic Places as prescribed by federal regulation and to determine State Archaeological Landmark Status as prescribed by state regulation. Ascertaining the nature of the deposits and cultural context of the site was also a prime consideration of the testing.

The highway project affecting the site will involve the construction of a major intersection for US 59 and Beltway 8. The project will involve construction of access roads as well as main lanes. Right-of-way requirements in the vicinity of the site will be $400 \mathrm{ft}$. 


\section{SITE DESCRIPTION AND TESTING PROCHDURES}

Site 41HR564 is located on a channelized drainage which flows into Keegans Bayou east of present US 59 (Fig. 1). The area is presently heavily overgrown with brush and tall grasses. The land has been cultivated and is presently used by locals as a dump site. Cultural evidence at the time of the initial survey was indicated by an Ensor dart point and a modified flake found in a dark soil exposed by the channelizing of the drainage.

At the time of testing no additional evidence was observed along the cut bank. In order to test for the presence of cultural material, two test units were excavated on the cut bank in the dark soil from which the original finds were located (Fig. 2). These units were approximately 1 meter by 1 meter and were excavated by pick and shovel in 10 am levels. Maximum depth excavated in the two test units was $40 \mathrm{~cm}$ and $50 \mathrm{~cm}$ respectively. All resulting soil was screened through 0.25 in. hardware cloth. No cultural evidence was recovered in either unit.

On the basis of the lack of any cultural material being recovered during testing operations at Site 41HR564, it is believed that the site is extremely sparse if extant at all and therefore warrants no further investigations. It is believed that the site does not meet the criteria for inclusion within the National Register of Historic Places and is not of State Archaeological Landmark status. 
This Page Redacted Per THC Policy 


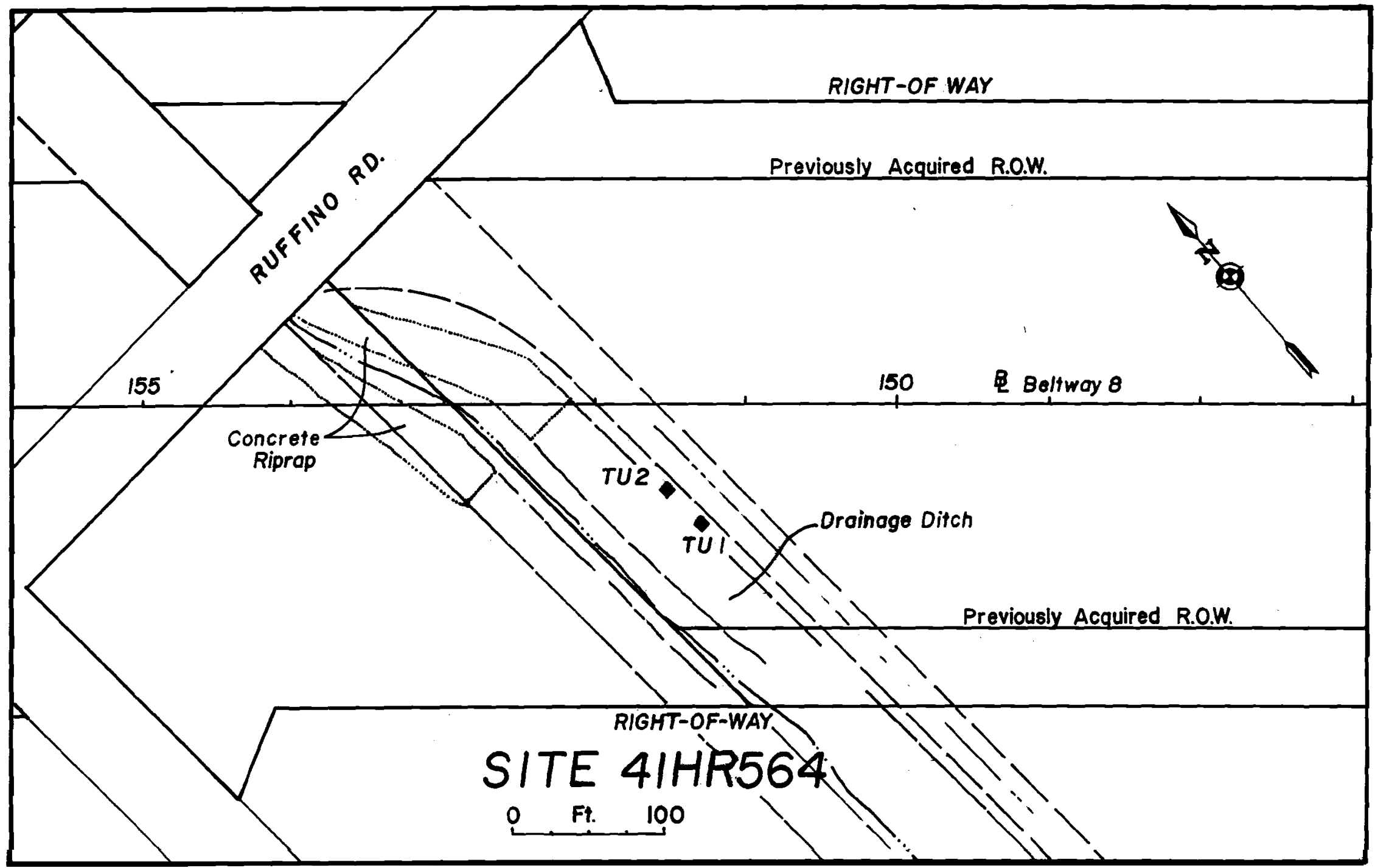

FIGURE 2. Project map of the site area showing locations of test units. 